\title{
PENERAPAN MODEL PEMBELAJARAN KOOPERATIF TIPE TEAM GAMES TOURNAMENT (TGT) BERBANTUAN MEDIA VISUAL UNTUK MENINGKATKAN AKTIVITAS DAN HASIL BELAJAR SISWA KELAS IIIC SD TUNAS HARAPAN JAYA DENPASAR
}

\author{
Anak Agung Oka Suciati \\ Program Studi Pendidikan Pancasila dan Kewarganegaraan, Institut Keguruan dan Ilmu \\ Pendidikan Saraswati Tabanan \\ e-mail : aaokasuciati@gmail.com
}

\begin{abstract}
Abstrak
Penelitian ini bertujuan untuk meningkatkan aktivitas dan hasil belajar siswa kelas IIIC SD Tunas Harapan Jaya Denpasar melalui penerapan model pembelajaran kooperatif tipe teams games tournament (TGT) berbantuan media visual. Penelitian ini merupakan Penelitian Tindakan Kelas yang diadopsi dari Arikunto 2014 dan dilaksanakan secara kolaboratif antara guru dengan peneliti. Subjek penelitian ini adalah siswa kelas IIIC SD Tunas Harapan Jaya Denpasar dengan jumlah siswa 34 orang siswa yang terdiri dari 15 siswa laki-laki dan 19 siswa perempuan. Data mengenai aktivitas belajar siswa diperoleh dengan menggunakan metode observasi dengan instrument yang berbentuk lembar observasi, sedangkan data mengenai hasil belajar siswa diperoleh dengan metode tes dengan instrumennya berupa tes hasil belajar. Data yang telah dikumpulkan, dianalisis menggunakan dekriptif kuantitatif. Hasil penelitian menunjukkan (1) terjadi peningkatan persentase rata-rata aktivitas belajar sebesar $15,47 \%$ dari $67,34 \%$ pada siklus I dengan kriteria cukup aktif menjadi $82,81 \%$ dengan kriteria aktif pada siklus II, dan (2) terjadi peningkatan persentase rata-rata hasil belajar siswa sebesar $6,77 \%$ dari $74,41 \%$ pada siklus I dengan kriteria sedang menjadi $81,18 \%$ pada siklus II dengan kriteria tinggi. Berdasarkan hasil analisis yang telah dilaksanakan disimpulkan bahwa penerapan model pembelajaran kooperatif tipe teams games tournament (TGT) berbantuan media visual dapat meningkatkan aktivitas dan hasil belajar siswa kelas IIIC SD Tunas Harapan Jaya Denpasar.
\end{abstract}

Kata Kunci: Teams Games Tournament (TGT), Media Visual, Aktivitas, Hasil Belajar Siswa

\begin{abstract}
This study aimed to increase the activity and learning outcomes of the fifth grade students of SD Tunas Harapan Jaya Denpasar through the application of the Teams Games Tournament (TGT) type of cooperative learning model assisted by visual media. This research was a Classroom Action Research adopted from Arikunto 2014 and carried out collaboratively between teachers and researchers. The subjects of this study were the fifth grade students of SD Negeri Tohpati with 34 students consisting of 15 male students and 19 female students. Data regarding student learning activities were obtained using the observation method with an instrument in the form of an observation sheet, while data on student learning outcomes was obtained by the test method with the instrument in the form of a learning outcome test. The data that heen collected were analyzed using quantitative descriptive. The results showed (1) there was an increase in the average percentage of learning activities by $15.47 \%$ from $67.34 \%$ in the first cycle with the criteria being quite active to $82.81 \%$ with active criteria in the second cycle, and (2) there was an increase in the percentage of the average student learning outcomes by $6.77 \%$ from $74.41 \%$ in the first cycle with medium criteria to $81.18 \%$ in the second cycle with high criteria. Based on the results of the analysis that has been carried out, it is concluded that the application of the Teams Games Tournament (TGT) type of cooperative learning model assisted by visual media can increase the activity and learning outcomes of the fifth grade students of SD Tunas Harapan Jaya Denpasar.
\end{abstract}


Keywords: Teams Games Tournament (TGT), Visual Media, Activities, Student Learning Outcomes

\section{PENDAHULUAN}

Pendidikan merupakan suatu hal yang sangat penting dalam kehidupan, baik dalam kehidupan berbangsa dan bernegara. Maju mundurnya suatu bangsa sebagain besar ditentukan oleh majunya mundurnya pendidikan di Negara tersebut. Begitu pentingnya peran dan tujuan pendidikan, maka mutu pendidikan haruslah ditingkatkan. Salah satu upaya untuk meningkatkan mutu pendidikan adalah melalui peningkatan kualitas pembelajaran. Selain peningkatan kualitas pembelajaran, pemerintah dan kalangan praktisi pendidikan juga sudah menyiapkan pengadaan fasilitas belajar, sumber belajar, pengembangan inovasi pembelajaran, dan penyempurnaan kurikulum yang semuanya bertujuan untuk meningkatkan mutu pendidikan (Santika, 2017).

Kurikulum yang berlaku dalam sistem pendidikan di Indonesia saat ini yaitu kurikulum 2013 revisi. Dalam kurikulum 2013 untuk sekolah dasar menerapkan sistem pembelajaran tematik terpadu. Pembelajaran tematik merupakan suatu pendekatan dalam pembelajaran yang secara sengaja mengaitkan atau memadukan beberapa kompetensi dasar dari kurikulum atau standar isi dari beberapa mata pelajaran menjadi satu kesatuan untuk dikemas dalam satu tema. Pembelajaran seperti ini bertujuan agar agar siswa dapat meningkatkan penguasaan konsep dengan dipadukannya antar mata pelajaran, dapat berpikir secara menyeluruh, dan mampu menghubungkan pengalaman yang dialami dengan konsep yang dimilikinya (Daryanto, 2014).

Pembelajaran tematik terpadu di sekolah dasar guru dituntut menguasai dan menggunakan model, metode, atau teknik pembelajaran yang tepat sehingga proses belajar mengajar menjadi menyenangkan bagi siswa. Dalam proses pembelajaran siswa dituntut untuk berpikir lebih aktif, kreatif, inovatif, cepat dan tanggap. Dalam kegiatan pembelajaran sangat diperlukan adanya aktivitas agar proses belajar mengajar berlangsung dengan baik. Menurut Sardirman (2014), aktivitas belajar adalah aktivitas yang bersifat fisik maupun mental. Dalam kegiatan belajar kedua aktivitas itu saling terkait. Selain itu siswa juga akan dilatih kemampuan berlogika dalam memecahkan suatu permasalahan, sehingga aktivitas belajar seperti ini akan mampu meningkatkan hasil belajar siswa.

Namun kenyataan Namun kenyataan dilapangan dalam proses pembelajaran masih ditemukan permasalahan-permasalahan yang terjadi berdasarkan hasil observasi dan wawancara guru kelas III SD Tunas Harapan Jaya 
Denpasar pada 28 November 2019 menunjukkan bahwa pembelajaran tema 3 sub tema 1, secara umum masih bersifat konvensional dimana guru lebih mendominasi pembelajaran dengan menggunakan metode ceramah, tanya-jawab maupun pemberian tugas di dalam kelas sehingga proses pembelajaran menjadi sangat membosankan. Dalam proses pembelajaran guru sangat jarang menggunakan media pembelajaran dan hanya terpaku pada materi yang terdapat pada buku ajar. Pembelajaran yang demikian mengakibatkan kebanyakan siswa ada yang mengantuk, bermain sendiri, dan suka rebut sendiri. Selain itu aktivitas dan minat belajar siswa rendah, sehingga tingkat pemahaman siswa terhadap materi yang diajarkan rendah. Aktivitas belajar siswa tergolong rendah dan berada pada kriteria sangat kurang aktif dengan skor rata-rata 19,54\%. Hal ini ditunjukkan berdasarkan hasil pengamatan bahwa dar 34 orang siswa hanya 7 orang aktivitas tinggi, 22 orang siswa dengan aktivitas sedang, dan 5 orang siswa dengan aktivitas rendah. Rendahnya aktivitas belajar siswa berdampak pada rendahnya hasil belajar siswa yang ditunjukkan dengan dari 34 siswa hanya 14 siswa yang memcapai KKM dan 20 siswa nilainya masih dibawah KKM.

Salah satu upaya yang dapat ditempuh oleh guru dalam rangka memperbaiki proses pembelajaran dengan menggunakan model pembelajaran kooperatif tipe Team Games Tournament
(TGT). Model pembelajaran tipe Team Games Tournament (TGT) adalah salah satu tipe model pembelajaran yang mudah diterapkan, melibatkan aktivitas seluruh siswa dan memungkinkan siswa dapat belajar lebih rileks, disamping membutuhkan tanggung jawab, percaya diri, menghargai sesama, disiplin, kooperatif, kerjasama dan keterlibatan belajar seluruh siswa. Menurut Taniredja (2014) pembelajaran kooperatif tipe Team Games Tournament (TGT) memiliki beberapa kelebihan yaitu: (1) dalam kelas kooperatif siswa memiliki kebebasan untuk berinteraksi dan menggunakan pendapatnya, (2) Rasa percaya diri siswa menjadi tinggi, (3) Perilaku mengganggu terhadap siswa lain menjadi kecil, (4) Motivasi belajar siswa bertambah, (5) Pemahaman yang lebih mendalam terhadap materi pelajaran, (6) Meningkatkan kebaikan budi, kepekaan, toleransi antara siswa dengan siswa dan antara siswa dengan guru, dan (7) Kerja sama antarsiswa akan membuat interaksi belajar dalam kelas menjadi hidup dan tidak membosankan.

Model pembelajaran kooperatif tipe Team Games Tournament (TGT) dalam penerapannya dapat dipadukan dengan media pembelajaran visual. Media visual adalah media pembelajaran yang menggunakan indera penglihatan yang berupa gambar, diagram, peta dan grafik. Media visual berfungsi untuk menarik perhatian, memperjelas sajian ide, menggambarkan fakta yang mungkin dapat 
mudah untuk dicerna dan diingat jika disajikan dalam bentuk visual. "Media pembelajaran visual dapat menumbuhkan minat siswa, memperkuat ingatan dan dapat memberikan hubungan antara isi materi dengan dunia nyata" (Arsyad, 2014:89). Penerapan model pembelajaran kooperatif tipe Team Games Tournament (TGT) berbantuan media visual diharapkan dapat meningkatkan aktivitas dan hasil belajar siswa.

Berdasarkan uraian yang telah dipaparkan diatas, peneliti tertarik untuk melakukan penelitian yang berjudul "Penerapan Model Pembelajarn Kooperatif Tipe Team Games Tournament (TGT) Berbantu Media Visual Untuk Meningkatkan Aktivitas dan Hasil Belajar Siswa Kelas IIIC SD Tunas Harapan Jaya Denpasar”. Penelitian ini bertujuan untuk menemukan celah, kekuatan, dan kelemahan. Sangat membantu peneliti ini untuk mengisi kekosongan dan menjadi penelitian yang berbeda (Wayan Swarniti, 2019). Tujuan penelitian ini adalah untuk mengetahui penerapan model pembelajaran kooperatif tipe Team Games Tournament (TGT) berbantuan media visual meningkatkan Aktivitas dan Hasil Belajar Siswa Kelas IIIC SD Tunas Harapan Jaya Denpasar.

\section{METODE}

Jenis penelitian ini adalah penelitian tindakan berbasis kelas (classroom-based action research) sebagai upaya perbaikan pembelajaran di sekolah pada umumnya dan di dalam kelas pada khususnya. Menurut Arikunto (2014:16) secara garis besar terdapat empat tahapan model peelitian tindakan, yaitu (1) perencanaan, (2) pelaksanaan, pengamatan, dan (4) refleksi. Penelitian ini dilakukan 2 siklus, setiap siklus dilakukan dalam 3 kali pertemuan yaitu 2 kali pertemuan untuk pelaksanaan tindakan dan satu kali pertemuan untuk tes hasil belajar.

Subjek penelitian ini adalah siswa kelas IIIC SD Tunas Harapan Jaya Denpasar tahun pelajaran 2019/2020 dengan jumlah siswa 34 orang siswa yang terdiri dari 15 siswa laki-laki dan 19 siswa perempuan. Penelitian tindakan kelas ini dilaksanakan hanya pada tema 4 sub tema. Penelitian ini dibantu oleh guru kelas III yang bertindak sebagai pengamat (observer) yang bertugas memberi masukan terhadap kekurangan dalam proses penelitian yang dilakukan.

Objek penelitian ini adalah Penerapan Model Pembelajarn Kooperatif Tipe Team Games Tournament (TGT) Berbantu Media Visual Untuk Meningkatkan Aktivitas dan Hasil Belajar Siswa Kelas IIIC SD Tunas Harapan Jaya Denpasar. Penelitian dilaksanakan pada bulan April 2020.

Metode pengumpulan data yang digunakan dalam penelitian ini adalah metode observasi dan tes. Data mengenai aktivitas belajar siswa diperoleh dengan menggunakan metode observasi dengan instrument yang berbentuk lembar observasi, 
sedangkan data mengenai hasil belajar siswa diperoleh dengan metode tes dengan instrumennya berupa tes hasil belajar. Lembar observasi yang digunakan dalam penelitian ini adalah jenis observasi terstruktur yakni dengan menggunakan pedoman observasi sebagai instrumen pengamatan. Adapun Indikator lembar observasi yang digunakan menurut Kuandar (2013:277) yaitu (a) siswa memperhatikan penjelasan guru; (b) siswa bertanya kepada guru maupun teman; (c) siswa menjawab pertanyaan yang diberikan guru; (d) siswa bekerja sama dalam kegiatan diskusi kelompok; (e) siswa menyampaikan pendapat berdasarkan hasil diskusi kelompoknya; dan (f) siswa menyimpulkan pembelajaran bersama dengan guru.

Data yang dikumpulkan dalam penelitian ini dianalisis dengan menggunakan analisis deskriptif kuantitatif.

\section{1) Analisis Data Aktivitas Belajar Siswa}

Analisis data pada siswa mengenai aktivitas belajar dilakukan melalui kegiatan observasi, yang datanya kemudian dianalisis dengan cara berikut. Menentukan aktivitas belajar dengan menggunakan rata-rata aktivitas siswa digunakan rumus sebagai berikut.

$$
\mathrm{M}=\frac{\sum X}{N}
$$

Keterangan:

$$
\begin{aligned}
& \mathrm{M}=\text { Skor rata-rata aktivitas siswa } \\
& \sum X=\text { Jumlah skor aktivitas }
\end{aligned}
$$

$N$ = Banyaknya siswa

(dalam Agung, 2014)

Menentukan persentase aktivitasnya digunakan rumus sebagai berikut.

$$
\mathrm{P}=\frac{\mathrm{M}}{\mathrm{SMI}} \times 100 \%
$$

Keterangan:

$$
\begin{aligned}
& \mathrm{P} \quad=\text { Persentase aktivitas belajar } \\
& \mathrm{M}=\text { Rata-rata } \\
& \mathrm{SMI}=\text { Skor Maksimal Ideal }
\end{aligned}
$$

Menentukan persentase rata-rata aktivitas belajar siswa setiap siklus dengan rumus:

Persentase rata-rata aktivitas belajar siswa setiap siklus:

jumlah persentase aktivitas belajar banyak pertemwan $\quad$ X $100 \%$

Untuk mengetahui tingkat ketercapaian aktivitas belajar digunakan konversi penilaian acuan patokan (PAP) skala lima tingkatan aktivitas belajar dapat menggunakan pedoman konverrsi PAP skala lima dilihat pada tabel 1 .

Tabel 1. Kriteria Aktivitas Belajar Siswa

\begin{tabular}{|c|c|}
\hline Persentase & $\begin{array}{c}\text { Kriteria Aktivitas } \\
\text { Belajar }\end{array}$ \\
\hline $90-100$ & Sangat Aktif \\
\hline
\end{tabular}




\begin{tabular}{|c|c|}
\hline 80-89 & Aktif \\
\hline $65-79$ & Cukup Aktif \\
\hline $55-64$ & Kurang Aktif \\
\hline $0-54$ & Sangat Kurang \\
& Aktif \\
\hline & (dalam Agung, 2014)
\end{tabular}

(dalam Agung, 2014)

\section{2) Analisis Data Hasil Belajar Siswa}

Data nilai hasil belajar (kognitif) diperoleh dengan menggunakan rumus:

$$
\begin{aligned}
& \text { Skorkgnitif } \\
& =\frac{\text { skor yang diperoleh }}{\text { skor maksimal }} \chi 100
\end{aligned}
$$

Nilai rata-rata siswa dicari dengan rumus sebagai berikut:

$$
x=\frac{\Sigma x}{N}
$$

Keterangan:

$$
\mathrm{X}=\text { Nilai rata-rata }
$$

$$
\begin{aligned}
& \Sigma \mathrm{X}=\text { Jumlah nilai siswa } \\
& \mathrm{N}=\text { Jumlah Peserta teks }
\end{aligned}
$$

Menentukan presentase rata-rata hasil belajar siswa dengan menggunakan rumus sebagai berikut :

$$
\mathrm{M}(\%)=\frac{M}{S M I} \times 100 \%
$$

(Agung, 2010:12)

Keterangan:

$$
\mathbf{M}(\%)=\text { Persentase hasil belajar siswa }
$$

$$
\begin{aligned}
& \mathrm{M}=\text { Angka rata-rata hasil belajar } \\
& \text { siswa } \\
& \text { SMI }=\text { Skor maksimal ideal hasil } \\
& \quad \text { belajar siswa }
\end{aligned}
$$
SMI = Skor maksimal ideal hasil belajar siswa

Setelah persentase rata-rata diperoleh, maka hasilnya dikonversikan ke dalam tabel 2 kriteria persentase hasil belajar sebagai berikut.

Tabel 2. Kriteria Hasil Belajar Siswa

\begin{tabular}{|l|l|}
\hline Persentase & Tingkat prestasi belajar \\
\hline
\end{tabular}




\begin{tabular}{|c|c|}
\hline 90-100 & Sangat tinggi \\
\hline $80-89$ & Tinggi \\
\hline $65-79$ & Sedang \\
\hline $40-64$ & Rendah \\
\hline $1-39$ & Sangat rendah \\
\hline
\end{tabular}

(Agung, 2010)

Menentukan persentase ketuntasan belajar (KB) klasikal dengan rumus:

$K B=\frac{\text { jumlah siswa tuntas }}{\text { Jumlah siswa dalam sampel }} \times \mathbf{1 0 0}$

\section{Indkator Keberhasilan}

Penelitian ini dikatakan berhasil jika:

1) Persentase rata-rata aktivitas belajar siswa minimal $80 \%$ berada pada kriteria aktif maka penelitian ini dikatakan berhasil.

2) Persentase rata-rata hasil belajar siswa minimal $80 \%$ berada pada Kriteria Baik.

3) Ketuntasan klasikal siswa mencapai $80 \%$ yang artinya sebayak $80 \%$ siswa memperoleh ketuntasan belajar mencapai KKM (80).

\section{HASIL PENELITIAN DAN} PEMBAHASAN

Penelitian diawali dengan kegiatan observasi peneliti pada siswa kelas IIIC SD Tunas Harapan Jaya Denpasar pada proses pembelajaran tema 3 sub tema 1 untuk mengetahui aktivitas dan hasil belajar siswa sebelum tindakan. Berdasarkan hasil observasi yang dilakukan proses pembelajaran secara umum masih bersifat konvensional dimana guru lebih mendominasi pembelajaran dengan menggunakan metode ceramah, tanya-jawab maupun pemberian tugas di dalam kelas. Dalam meyampaikan materi guru sangat jarang menggunakan media pembelajaran dan hanya berpatokan pada materi yang ada pada buku ajar. Proses belajar mengajar hanya sebatas pada guru memberikan penjelasan kepada siswa kemudian dilanjutkan dengan pengerjaan soal pada buku ajar. Proses belajar mengajar seperti ini sangat membosankan sehingga menyebabkan siswa kurang aktif dan terlihat kurang termotivasi. Hal ini berdampak pada rendahnya aktivitas belajar siswa. Aktivitas belajar siswa tergolong rendah dan berada pada kriteria sangat kurang aktif dengan skor rata-rata $19,54 \%$. Hal ini ditunjukkan berdasarkan hasil pengamatan bahwa dar 34 orang siswa hanya 7 orang aktivitas tinggi, 22 orang siswa dengan aktivitas sedang, dan 5 orang siswa dengan aktivitas rendah. 
Rendahnya aktivitas belajar siswa berdampak pada rendahnya hasil belajar siswa yang ditunjukkan dengan ketuntasan klasikal sebesar 29,57\% dari 34 siswa hanya 10 siswa yang memcapai KKM dan 24 siswa nilainya masih dibawah KKM. Data pra siklus yang diperoleh belum mencapi indikator keberhasilan yang ditetapkan. Data ini selanjutnya menjadi bahan refleksi awal untuk memperbaiki proses pembelajaran melalui Penelitian Tindakan Kelas secara bersiklus yang terdiri dari perencanaan, observasi, pelaksanaan dan refleksi siklus I dengan siklus II. Adapun rekapitulasi data aktivitas dan hasil belajar siswa dari pra siklus, siklus I dan siklus II secara berturutturut disajikan pada tabel 3, 4, dan 5 berikut.

Tabel 3. Tabel Rekapitulasi Data

Tabel 4. Tabel Rekapitulasi Data Hasil Belajar Siswa

\begin{tabular}{|c|c|c|c|l|}
\hline Variabel & $\begin{array}{c}\text { Persentase } \\
\text { rata-rata }\end{array}$ & $\begin{array}{c}\text { Persentase } \\
\text { Ketuntasan } \\
\text { Klasikal }\end{array}$ & Kreteria & \multicolumn{1}{|c|}{ Keterangan } \\
\hline Prasiklus & $59,85 \%$ & $29,57 \%$ & Rendah & $\begin{array}{l}\text { Berada pada kategori rendah } \\
\text { dengan 10 siswa tuntas dan } 24 \\
\text { siswa belum tuntas atau } \\
\text { dibawah KKM }\end{array}$ \\
\hline Siklus I & $74,41 \%$ & $61,76 \%$ & Sedang & $\begin{array}{l}\text { Berada pada kategori sedang } \\
\text { dengan 21 siswa tuntas dan 13 } \\
\text { siswa belum tuntas atau } \\
\text { dibawah KKM }\end{array}$ \\
\hline Siklus II & $81,18 \%$ & $91,18 \%$ & Tinggi & $\begin{array}{l}\text { Berada pada kategori tinggi } \\
\text { dengan 31 siswa tuntas dan 3 } \\
\text { siswa belum tuntas atau } \\
\text { dibawah KKM }\end{array}$ \\
& & & &
\end{tabular}




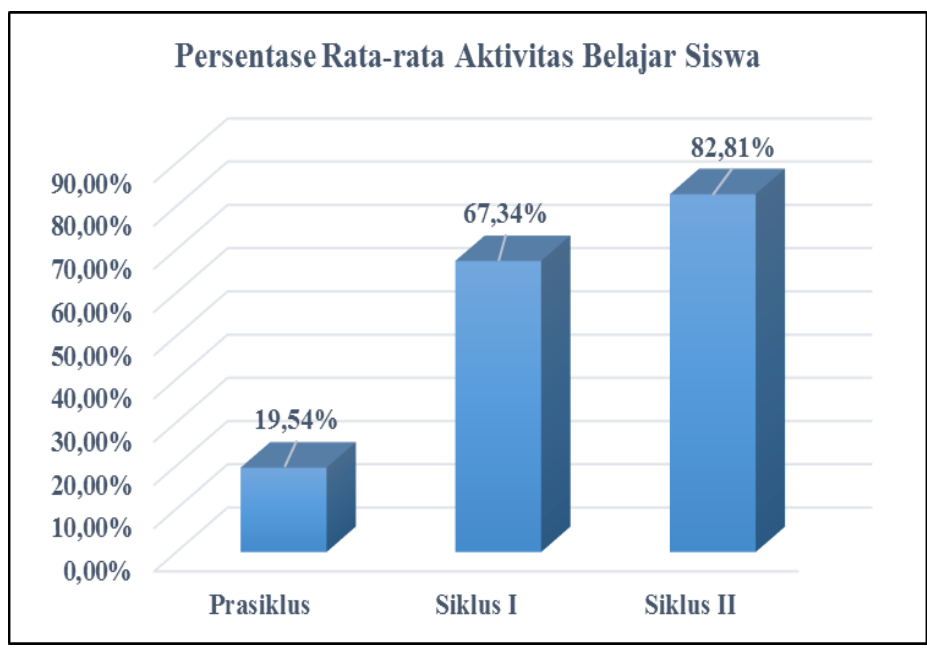

Gambar 1. Rekapitulasi Data Persentase Rata-rata Aktivitas Belajar Siswa

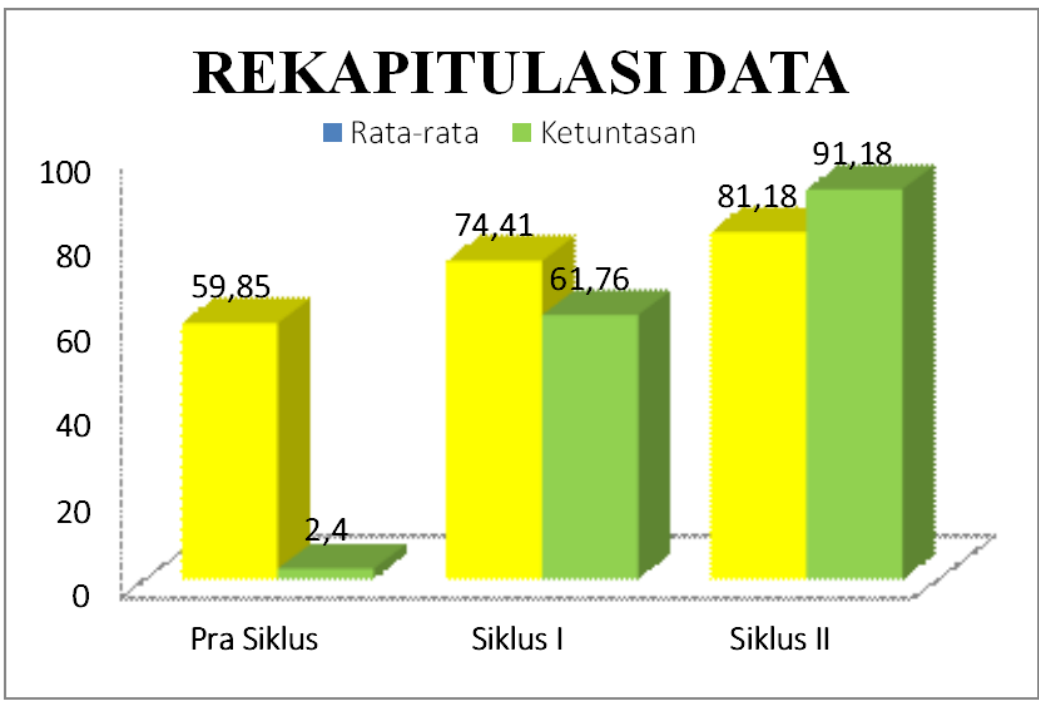

Gambar 2. Rekapitulasi Data Persentase Rata-rata Hasil Belajar Siswa

Berdasarkan tabel dan grafik diatas maka dapat dilihat terjadi peningkatan aktivitas dan hasil belajar siswa setelah dilakukan tindakan pada siklus I dan II, walaupun pada siklus I hasil yang diperoleh belum optimal dan belum memenuhi kriteria yang diharapkan. Pada siklus I persentase rata-rata aktivitas belajar siswa sebesar $67,34 \%$ berada pada kriteria cukup aktif.
Hasil tersebut belum memenuhi indikator keberhasilan yang diharapkan. Begitu pula dengan hasil belajar siswa, dimana persentase rata-rata hasil belajar siswa sebesar $74,41 \%$ dengan ketuntasan klasikal sebesar 61,76 \% berada pada kategori sedang dengan 21 siswa tuntas dan 13 siswa belum tuntas atau dibawah KKM sehingga 
belum mencapai indikator keberhasilan yang diharapkan

Dalam pelaksaan siklus I masih terdapat kekurangan, baik berasal dari guru maupun dari siswa. Kekurangan ini diantaranya yaitu: 1) Siswa belum terbiasa dengan model pembelajaran yang diterapkan karena model pembelajaran kooperatif tipe Team Games Tournament (TGT) berbantuan media visual merupakan hal baru untuk mereka. 2) Guru masih kebingungan dalam menerapkan model pembelajaran kooperatif tipe Team Games Tournament (TGT) berbantuan media visual dalam proses belajar mengajar karena kekurang pahaman guru terhadap model pembelajaran ini. 3) Sebagian besar siswa kurang berani mengemukakan pendapat atau pertanyaan kepada guru, serta mengemukakan simpulan dari materi yang telah dipelajari karena takut salah dan terpaku dengan simpulan yang dikemukakan oleh siswa lain 4) Masih kurangnya media dan sumber belajar yang bervariatif untuk lebih menarik perhatian siswa dan menciptakan suasana yang interaktif dalam pembelajaran, 5) Siswa belum mampu belajar secara berkelompok dan bekerjasama dalam penyelesaian masalah. Hal ini disebabkan karena siswa belum mampu mengkoordinir kelompoknya dengan baik dan juga siswa belum mampu menghargai pendapat temannya dan kebanyakan siswa mengandalkan temannya yang pintar dalam kelompoknyadan 6) Siswa belum mampu mengatur waktu dalam mengerjakan tugas-tugas yang diberikan oleh guru, sehingga ketika waktu yang diberikan telah habis dan tugas tersebut belum selesai dikerjakan.

Berdasakan kekurangan yang dihadapi dalam kegiatan pembelajaran pada siklus I, peneliti bersama dengan guru mendiskusikan perbaikan tindakan untuk selanjutnya diterapkan pada siklus II. Perbaikan tindakan yang dilakukan, diantaranya sebagai berikut:1) Memberikan penjelasan langkah-langkah pembelajaran yang akan dilaksanakan dengan jelas dan memberikan jeda waktu siswa untuk mengemukakan pertanyaan jika ada yang kurang dalam pembelajaran tema untuk memastikan seluruh siswa memahami setiap langkah pembelajaran yang akan dilakukan. 2) Mmeberikan penjelaskan kepada guru langkah-langkah pembelajaran kooperatif tipe Team Games Tournament (TGT) berbantuan media visual dan cara mengimplementasikan dalam proses pembelajaran. 3) Mengarahkan siswa dalam membuat simpulan dengan memberikan pertanyaan pancingan yang mengarah pada simpulan yang diharapkan. Dalam diskusi kelas, guru menunjuk siswa secara acak untuk menyimpulkan konsep-konsep yang telah dipelajari. Setiap siswa diberikan kesempatan untuk menanggapi simpulan temannya. Agar siswa tidak mengalami miskonsepsi, guru memberikan penjelasan. 4) Menggunakan media dan menerapkan variasi pembelajaran yang variatif untuk menumbuhkan minat siswa serta interaksi dalam pembelajaran. 5) Mendistribusikan 
tugas pada masing-masing kelompok untuk meningkatkan kerjasama dalam kelompok.

6) Mengingatkan alokasi waktu yang masih tersisa 10-15 menit sebelum waktu habis untuk melakukan kegiatan, mengingatkan siswa agar setiap siswa turut aktif dalam menyelesaikan tugas kelompok yang diberikan sehingga tugas tersebut selesai tepat pada waktunya. Selain itu, membiasakan siswa untuk menjawab pertanyaan-pertanyaan yang dianggap mudah terlebih dahulu, sehingga waktu yang diperlukan menjadi tepat dengan waktu yang disediakan.

Setelah melakukan perbaikan proses pembelajaran pada siklus II pembelajaran menjadi lebih kondusif dan interaktif sehingga aktivitas dan hasil belajar siswa mengalami peningkatan. Persentase rata-rata aktivias belajar siswa mengalami peningkatan sebesar $15,47 \%$ dari $67,34 \%$ pada siklus I dengan kriteria cukup aktif menjadi $82,81 \%$ dengan kriteria aktif pada siklus II. Peningkatan ini juga terjadi pada hasil belajar siswa sebesar, pada sikuls I memperoleh persentase rata-rata $74,41 \%$ dengan ketuntasan klasikal 61,76\% sedangkan pada siklus II memperoleh persentase rata-rata sebesar $81,18 \%$ dengan kriteria tinggi dan ketuntasan klasikal sebesar $91,18 \%$ sehingga terjadi peningkatan persentase rata-rata hasil belajar dari siklus I ke siklus II sebesar $6,77 \%$ dan peningkatan ketuntasan klasikal sebesar $10 \%$ yakni dari 34 siswa sebanyak 31 siswa tuntas dan 3 siswa belum tuntas atau dibawah KKM.
Berdasarkan data yang diperoleh pada siklus II maka indikator keberhasilan yang diharapkan dalam penelitian sudah terpenuhi. Hal ini terlihat dari data yang diperoleh yaitu aktivitas belajar siswa telah mencapai persentase rata-rata $80-89 \%$ berada pada kriteria aktif, dan hasil belajar siswa telah mencapai persentase rata-rata 80-89\% berada pada kriteria tinggi, serta ketuntasan klasikal juga mencapai $80 \%$ siswa mendapat nilai sesuai dengan KKM. Data tersebut dapat membuktikan Penerapan model pembelajaran kooperatif tipe Team Games Tournament (TGT) berbantuan media visual dapat digunakan untuk meningkatkan aktivitas dan belajar siswa kelas IIIC SD Tunas Harapan Jaya Denpasar. Hal ini sejalan dengan penelitian yang dilakukan oleh Dewi, (2016) yang menyatakan bahwa penerapan model pembelajan kooperatif tipe team games tournament (TGT) dapat meningkatkan aktivitas dan hasil belajar matematika siswa kelas Va SDN 10 Metro Timur. Penenlitian ini juga didukung oleh penelitian sebelumnya dari Astuti, (2013) yang menyatakan bahwa guru berhasil dalam menerapkan model pembelajaran kooperatif tipe Teams Games Tournament (TGT) pada mata pelajaran sosiologi secara menarik dan menyenangkan yang membuat siswa lebih aktif dalam pembelajaran, sehingga hasil belajar siswa mengalami peningkatan. Hal ini dikarenakan melalui penerapan model pembelajaran kooperatif tipe Team Games Tournament (TGT) dalam proses 
pembelajaran maka siswa akan terlibat langsung secara aktif dalam proses pembelajaran karena di dalamnya menegandung permaianan. Model pembelajaran TGT memungkinkan siswa untuk belajar dalam suasana belajar yang lebih menyenangkan dengan memberikan kesempatan kepada siswa menumbuhkan rasa tanggung jawab baik terhadap diri sendiri maupun terhadap tim belajar, bekerja sama dalam proses akademik, melakukan persaingan secara sehat, dan memudahkan dalam proses pemahaman terhadap materi tertentu. Pembelajaran yang demikian dapat menjadikan siswa lebih aktif (Devioga, 2014).

Dengan model pembelajaran kooperatif tipe Teams Games-Tournament (TGT) dapat menjadikan peserta didik lebih bersemangat dalam pembelajaran dan menciptakan suasana kelas yang lebih menyenangkan sehingga aktivitas dan hasil belajar siswa meningkat. Selain itu, untuk membantu siswa dalam memahamai materi pelajaran, dalam penelitian ini juga digunakan media visual dalam menyampaikan pesan pembelajaran. Media pembelajaran ini digunakan dalam rangka hubungan (komunikasi) dalam proses pembelajaran antara pengajar dan pembelajar. Dalam pembelajaran di sekolah dasar media visual sangat cocok untuk digunakan karena siswa dapat melihat dan mendengarkan langsung apa yang mereka pelajari. Media visual merupakan sumber belajar yang berisikan pesan atau materi pelajaran yang dibuat secara menarik dalam bentuk kombinasi gambar, teks, gerak, dan animasi yang disesuaikan dengan usia siswa sehingga pembelajaran akan menyenangkan dan tidak membosankan. Media visual memegang peranan penting dalam membantu tercapainya proses belajar yang optimal. Peranan media visual dalam proses pembelajaran yaitu dapat menarik perhatian dan mempercepat daya serap siswa dalam memahami pelajaran yang disampaikan serta mengaktifkan siswa sehingga aktivitas belajar khususnya kompetensi pengetahuan dapat optimal (Arsyad, 2014). Pembelajaran kooperatif tipe Teams Games-Tournament (TGT) sangat sesuai jika diintegrasikan dengan media visual. Melalui model pembelajaran kooperatif tipe Teams GamesTournament (TGT) berbantuan media visual, siswa dapat lebih mudah menyerap pelajaran dan mengingat karena diberikan gambaran yang lebih nyata melalui media visual. Hal ini sejalan dnegan penelitian yang dilakukan oleh Lumbantobing, (2019) bahwa penerapan model pembelajaran kooperatif Teams Games-Tournament (TGT) berbantuan media audio visual dapat meningkatkan prestasi belajar siswa diukur dari aspek afektif dan psikomotor.

\section{KESIMPULAN DAN SARAN}

\section{Simpulan}

Berdasarkan hasil penelitian dan pembahasan dapat disimpulkan bahwa implementasi model pembelajaran kooperatif tipe team games tournament 
(TGT) berbantu media visula dapat meningkatkan aktivitas dan hasil belajar siswa kelas IIIC SD Tunas Harapan Jaya Denpasar yang dibuktikan dengan adanya peningkatan persentase rata-rata aktivitas dan hasil belajar siswa. Skor persentase ratarata aktivitas belajar siswa pada siklus I yaitu sebesar $67,34 \%$ dan pada siklus II $82,81 \%$. Terjadi peningkatan dari siklus I ke siklus II sebesar $15,47 \%$. Peningkatan ini juga terjadi pada hasil belajar siswa sebesar, pada sikuls I memperoleh persentase ratarata $74,41 \%$ dengan ketuntasan klasikal $61,76 \%$ sedangkan pada siklus II memperoleh persentase rata-rata sebesar $81,18 \%$ dengan kriteria tinggi dan ketuntasan klasikal sebesar 91,18\% sehingga terjadi peningkatan persentase rata-rata hasil belajar dari siklus I ke siklus II sebesar $6,77 \%$ dan peningkatan ketuntasan klasikal sebesar $10 \%$ yakni dari 34 siswa sebanyak 31 siswa tuntas dan 3 siswa belum tuntas atau dibawah KKM. Berdasarkan data yang diperoleh pada siklus II maka indikator keberhasilan yang diharapkan dalam penelitian sudah terpenuhi.

\section{Saran}

Berdasarkan penelitian yang telah dilakukan, peneliti mempunyai beberapa saran sebagai berikut. Kepada siswa disarankan agar belajar dengan baik, fokus dan aktivitas belajar yang baik yang telah diperoleh sebaiknya dipertahankan. Kepada guru diharapkan menerapkan model pembelajaran kooperatif tipe Teams GamesTournament berbantuan media visual dalam pembelajaran sebagai alternatif dalam mengatasi rendahnya aktivitas dan hasil belajar siswa. Kepada Sekolah Mengingat penerapan model pembelajaran kooperatif tipe Teams Games-Tournament berbantuan media visual dapat mendorong siswa lebih aktif dan dapat meningkatkan aktivitas belajar siswa, diharapkan setiap sekolah dapat menerapkan medel pembelajaran tersebut sebagai alternatif dalam upaya meningkatkan aktivitas belajar siswa kelas III yang memiliki masalah yang sama dengan masalah yang ditemukan dalam penelitian ini. Kepada Peneliti Lain diharapkan memanfaatkan hasil penelitian ini sebagai acuan penelitian yang akan dilakukan. Selain itu, peneliti lain disarankan melakukan penelitian yang sejenis untuk mengetahui efektifitas Penerapan model pembelajaran kooperatif tipe Teams Games-Tournament berbantuan media visual pada sekolah yang berbeda.

\section{DAFTAR PUSTAKA}

Astuti, Ayu. 2013. Model Pembelajaran Kooperatif Tipe TGT (Teams Games Tournament) Untuk Meningkatkan Prestasi Belajar Sosiologi. Skripsi. Tidak diterbitkan. FKIP, Universitas Sebelas Maret

Daryanto. (2014). Pembelajaran tematik, terpadu, terintegrasi (kurikulum 2013). Yogyakarta: Gava Media.

Devioga, F. (2014). Efektivitas Motode Pembelajaran Kooperatif Tipe TGT Terhadap Peningkatan Aktifitas dan Prestasi Belajar Kelas X Mata Pelajaran Teknik Listrik di SMKN 
2 Yogyakarta. Yogyakarta: Universitas Negeri Yogyakarta.

Kuandar. 2013. Langka Mudah Penelitian Tindakan Kelas (sebagai Pengembangan Profesi Guru). Jakarta: Raja Grafindo Persada.

Lumbantobing, R.E. 2019. Penerapan Model Pembelajaran Kooperatif Teams Games Tournament (TGT) Berbantuan Media Audio Visual Untuk Meningkatkan Prestasi Belajar Siswa Pada Mata Pelajaran Sejarah di Kelas X Tata Kecantikan 1 SMK Negeri 6 Yogyakarta. Skripsi. Tidak Diterbitkan. Program Studi Pendidikan Sejarah, Jurusan Pendidikan Ilmu Pengetahuan Sosial, FKIP, Universitas Sanata Dharma.

Santika, I Gusti Ngurah. 2017. Kepala Sekolah Dalam Konsep Kepemimpinan Pendidikan: Suatu Kajian Teoritis. Widya Accarya. 7 (1).

Sardiman. 2014. Interaksi dan Motivasi Belajar Mengajar. Rajawali Pers. Jakarta
Taniredja, Tukiran, dkk. 2014. Model-model Pembelajaran Inovatif. Alfabeta: Bandung.

Wayan Swarniti, N. (2019). The Translation Procedures of Bible Translation. 5(2), 187-196. https://doi.org/10.22225/jr.5.2.1277.18 7-196 